\title{
UDC 621.914.1
}

\section{TYPES OF SPECIAL-FORM MILLS DEFECTS FOR KZH20 MACHINE-TOOL}

\author{
Aleksander Sładkowski ${ }^{1}$; Vladislav Ruban² \\ ${ }^{1}$ Silesian University of Technology, Katowice, Poland \\ ${ }^{2}$ National Metallurgical Academy of Ukraine, Dnipro, Ukraine
}

\begin{abstract}
Summary. The increase of machining efficiency, the improvement of cutting tools service characteristics and optimization of machining modes are the important tasks of mechanical engineering. Special-form mills for wheel milling machines KZh20 are used at locomotive depots for restoration of the wheelset working profile without rolling off the locomotive. Special-form mill is a cutting tool in which the cutting edge is not parallel to the rotation axis and is a set of curves and straight lines, and the profile of the wheel working surface is formed by rotating the cutting edge relatively to the tool axis. The tool life is due to the operating conditions of the locomotive wheels resulting in premature wear with the occurrence of sliders, weld-on deposits and other defects that require special modes of wheelset milling. The most characteristic defects of special-form mills for KZh20 machine tool are defined. According to the impact on the service life of special-form mills, there are two main groups of defects related to the manufacturing quality and tool setting, as well as machining modes.

Key words: special-form mills, KZh20 wheel milling machine, cutting elements, failures of special-form mills, reliability, service life.
\end{abstract}

Statement of the problem. The process of milling of the wheelset working surface is carried out by special-form mills on KZh20 machine tools under of intermittent cutting conditions.

The experience of special-form mills operation for KZh20 machine tools indicates that defects of cutting elements are not the main reason of loss of working capacity of form milling cutters.

The development of science and technology puts forward new increased requirements for investigations in order to determine the defects of special-form mills for KZh20 machine tools, which affect the service life, tool costs and increase the cost of wheelsets restoration process.

Analysis of available investigations results. Milling for the rotating bodies machining was used for the first time in 1938. This method is based on the kinematic scheme, combining uniform rotation of the workpiece and the tool around their axes with different angular velocities [1]. In all cases, the mill performs the working motion which determines the cutting speed, and the feed motion is transmitted to the workpiece or to the workpiece and the tool.

Since 1945, to restore the working profile of the rolling stock wheels, several designs of special-form mills were proposed at different times. Such mills, despite the complexity in manufacturing, adjustment and repair, were used in wheels machining without rolling off the locomotive.

In 1960, the developments of form mills were carried out at Rostov Institute of Railway Transport Engineers (RIRTE) (Figure 1) and All-Union Scientific-Research Instrumental Institute (AUSRII) (Figure 2).

The mill disks 1 (Figure 1) are assembled on the mandrel in such a way that the knives cutting edges 2 are arranged in the spiral with $30^{\circ}$ angle. Knives 2 in disks are located at $10^{\circ}$ 
angle, paired ones are inclined in one direction, and nonpaired - in the other. The front angle of the mill is $-5^{\circ}$, and the rear one is set to $6^{\circ}$. Mill cutters are equipped with plates made of hard alloy T5K10.

AUSRII form mill (Figure 2), used on wheel milling machines of KZh20 model for the restoration the wheelset working profile without rolling off the locomotive, consists of 10 plates (knives).

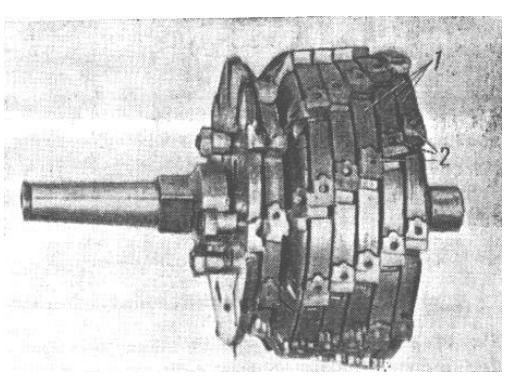

Figure 1. RIRTE experimental mill

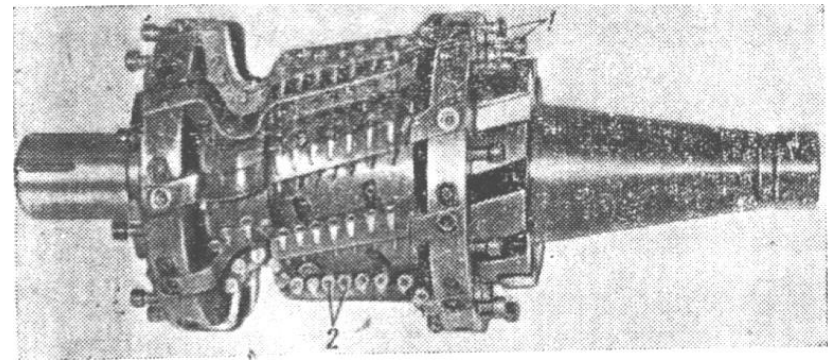

Figure 2. AUSRII mill design

12 cutters with $12 \mathrm{~mm}$ diameter and $12.5 \mathrm{~mm}$ height are installed in each plate, and mills with $16 \mathrm{~mm}$ cutting elements diameter are proposed as well. The form mill is equipped with hard-alloy cutting elements of T14K8 grade. In AUSRII cutter, the front angle is minus $8^{\circ}$, the rear one is $8^{\circ}$, the plates (knives) inclination angle and the spiral angle of the cutting surface is $15^{\circ}$. The mill diameter corresponding to tread circular rolling is $210 \mathrm{~mm}$. Each knife has 12 cylindrical cutters, center-to-center spacing is $18 \mathrm{~mm}$. In the following years, the engineer Yu. L. Borovyi (AUSRII) was working on the mill design.

On January 1, 1988, the combined AURIIRT rolling surface profile for wheelset tread machining was introduced in the railway network and, consequently, in mining and metallurgical industry. For this purpose, the mill of a new design was developed in the branch of PCB CT MPS (Torzhok). There are the following well-known designs: the mill of combined profile for wheelset machining passport I582.00.00-PS, I583.00.00-PS, mills for wheels tread turning by the profile of I707-I716 types, specifications TC 32 TsT 2222-95, the mill for the restoration of wheel profile of the railway transport rolling stock (patent of Ukraine No25091, IPC B 23. From 5/11. 5/14 published 25.12.98,) interlocking form mill (patent of Ukraine No25406, IPC B23. C5/00 published 25.12. 98 p) [2, 3].

The best design and technical solutions became the basis for the design of a special interlocking form mill, and were used while designing of a new SMI locomotive mills.

The special interlocking form mill of SMI design (Figure 3) is used at present for reconstructive maintenance of the working surface profile of wheelset without rolling off the locomotive on wheel milling machines of KZh20 model and their modifications at locomotive depots of main and industrial rail transport of Ukraine and a number of CIS countries. The form mill is equipped with hard-alloy cutting elements of T14K8 grade. In SMI mill the front angle is minus $8^{\circ}$, the rear is $8^{\circ}$, the angle of tool holders (knives) inclination is $15^{\circ}$. The mill diameter corresponds to the tread circular rolling circle, $210 \mathrm{~mm}$. Each cylinder holder is fitted with 13 cylindrical cutters, center-to-center spacing is $14 \mathrm{~mm} \mathrm{[4].}$

Special interlocking form mills consist of the cutter housing 1 (Figure 3), in the grooves of which cutter holders 2 are installed. The cutter holders fastening is carried out by screws 3 and wedge-shaped blocks 4 , the end of the tool holder on the flange side must be tightened to base ring 5 with by screw 8 . The tool holders are installed in the grooves of the housing in a 
strictly defined order and should be marked according to the grooves numbers. The left (base) ring 5 and the right one 6 are attached to the housing by screws 7 .

The cutting elements of special interlocking form mills are carbide cylindrical cutting elements $9[5,6]$, which are inserted into the holes of the tool holders and are fastened in them by screws 10 and nuts 13 . Compensating washers 12 with different thickness are installed under the cutting elements. Due to them the required accuracy of cylindrical cutting elements arrangement during adjustment of special interlocking form mills on the necessary working surface profile of the wheels of rail transport is reached. According to the design the left and the right special form mills are similar.

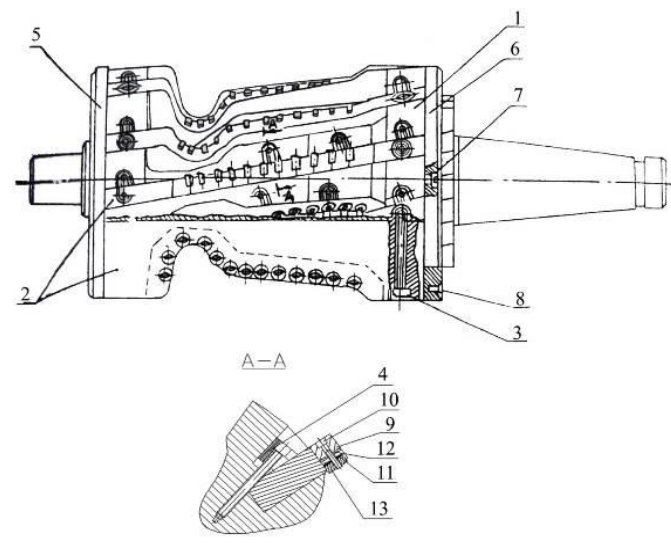

Figure 3. Special form mill of design SMI

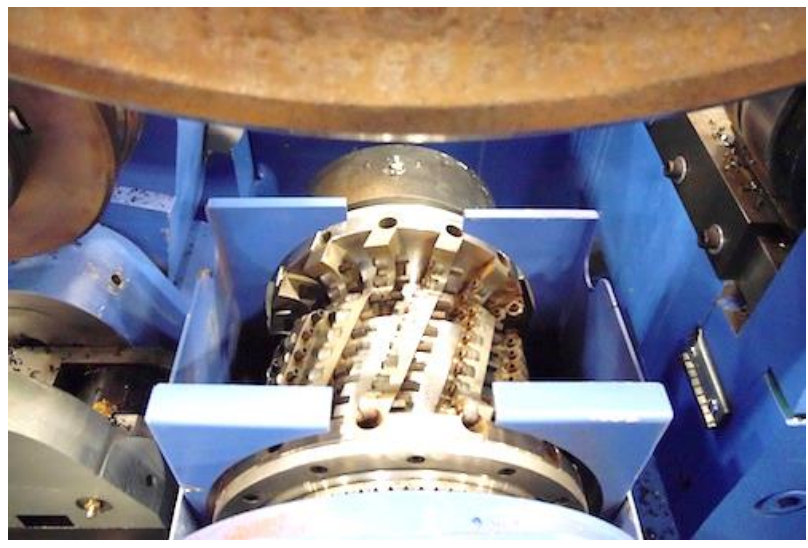

Figure 4. Mill of «Simmons-Stanray» on TN-84C machine tool

The «Simmons-Stanray» company [7] defines the advantage of milling as that one which has the best characteristics of cutting dynamics, in the mills (Figure 4) produced by this company from 115 to 185 cutting surfaces are used, when turning - one cutting surface. During milling, the locomotive wheel only rotates, while cutting for turning is provided by the wheel rotation. The quality of the working surface of the profile is $0.25 \mathrm{~mm}$. The form mill consists of 16 knives of the form profile installed with the inclination in the mill housing. 184 carbide cutting elements are installed in the cylindrical slots of the knives. Knives fastening in the housimg is carried out by wedges, screws and face covers, and fastening of cutters in knives by screws through internal openings. In one of end faces of the mill openings for console fastening of the tool to machine spindle are provided.

The advantages of the form mill of Simmons Machine Tool Corporation, USA are as follows: smoothness of cutting, good shaving crushing, increased total life service of cutting edges due to the possibility of cutters rotation and reinstallation.

The disadvantages of the mill are in the fact that its knives fail relatively quickly due to the intensive wear of the surface between the mill cutters.

The objective of the paper is to investigate and determine the main defects of special form cutters for KZh20 machine tools and the reasons affecting their occurrence.

Presentation of the main material. The important task of mechanical engineering is to increase machining productivity, improve the cutting tools performance and optimize the cutting modes.

Most of the working profile of the wheels is restored without rolling off the locomotive during TO-3, TO-4, TR-1, TR-2. At present, wheel milling machines KZh20 [8, 9] (Figure 5) of various modifications are used at various locomotive depots for the restoration of the working profile of wheelset without rolling off the locomotive. 
According to «Ukrzaliznytsia» report, the rolling stock consists of [10]: locomotives 250 units, including: electric locomotives - 1469 units; diesel locomotives - 429 units; railcar rolling stock, including: diesel trains - 282 units; rail buses - 17 units; electric trains 1391 units; Hyundai high-speed electric trains - 10 units; «Tarpan» high-speed electric trains 2 units; interregional locomotive trains -2 units ( 5 passenger cars).

The rolling stock of Ukrzaliznytsia [11] is more than $3 / 4$ worn out. According to the rolling stock renewal program it is planned to purchase until 2021: locomotives - 262 units; railcar rolling stock -46 units.

The most obsolete traction rolling stock requires more than $40-60 \%$ additional repair costs.

PJSC «Ukrzaliznytsia» includes the following regional branches: 1. «Odessa Zaiznytsia»- 7 locomotive depots; 2. «Lviv Zaiznytsia»- 8 locomotive depots; 3. «Prydniprovska Zaiznytsia» - 6 locomotive depots; 4. «Pivdenna Zaiznytsia»-10 locomotive depots; 5. «Pivdenno-Zakhidna Zaiznytsia»-9 locomotive depots; 6. «Donetsk Zaiznytsia» 5 locomotive depots, 2 electric multiple unit depot.

At locomotive depots KZh20 machine tools are installed, for example in Dnipropetrovsk locomotive depot - 1 machine tool, and at locomotive depots Nyzhniodnipropetrovsk Knot and Kryvyi Rih 2 machine tools for each.

Wheel milling machines KZh20 (Figure 5) [12] and their modifications are installed at metallurgical enterprises.

According to $\mathrm{MK}$ «Zaporizhstal» -82 locomotives are included to the railway industry [13]. There are $2 \mathrm{KZh} 20$ machines installed in the locomotive repair shop.

According to PJSC «ArcelorMittal Kryvyi Rih» [14], the total number of locomotives is 199 units servicing GOK steel production of, $2 \mathrm{KZh} 20$ machine tools are also installed.

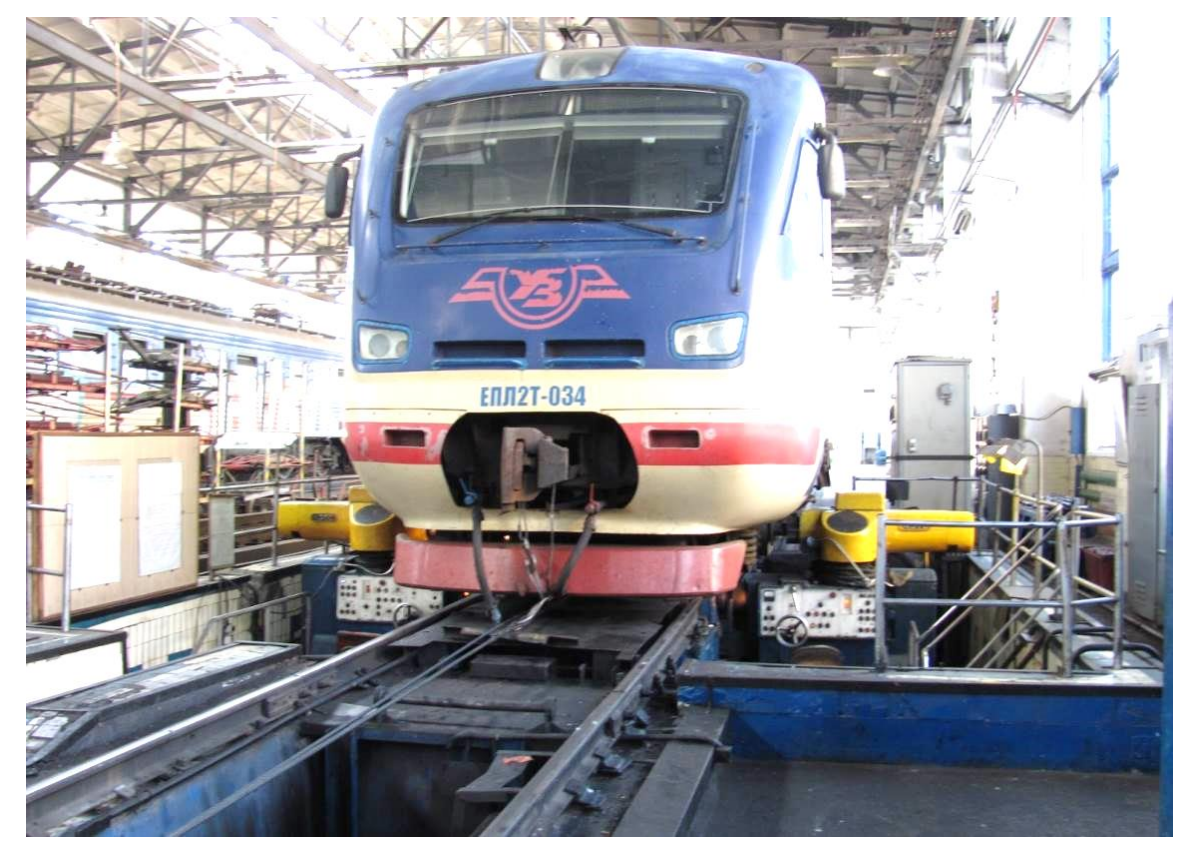

Figure 5. Motor car on the wheel milling machine KJ20

Machine tools of this type appeared in the early 50's in the United States, later in the USSR [15]. European countries use wheel lathes, and in the United States wheel milling machines are used. 
Form mill (Figure 6) is a cutting tool in which the cutting edge is not parallel to the axis of rotation and is a set of curves and straight lines, and the profile of the working surface of the wheel is formed by rotating the cutting edge relatively to the tool axis.

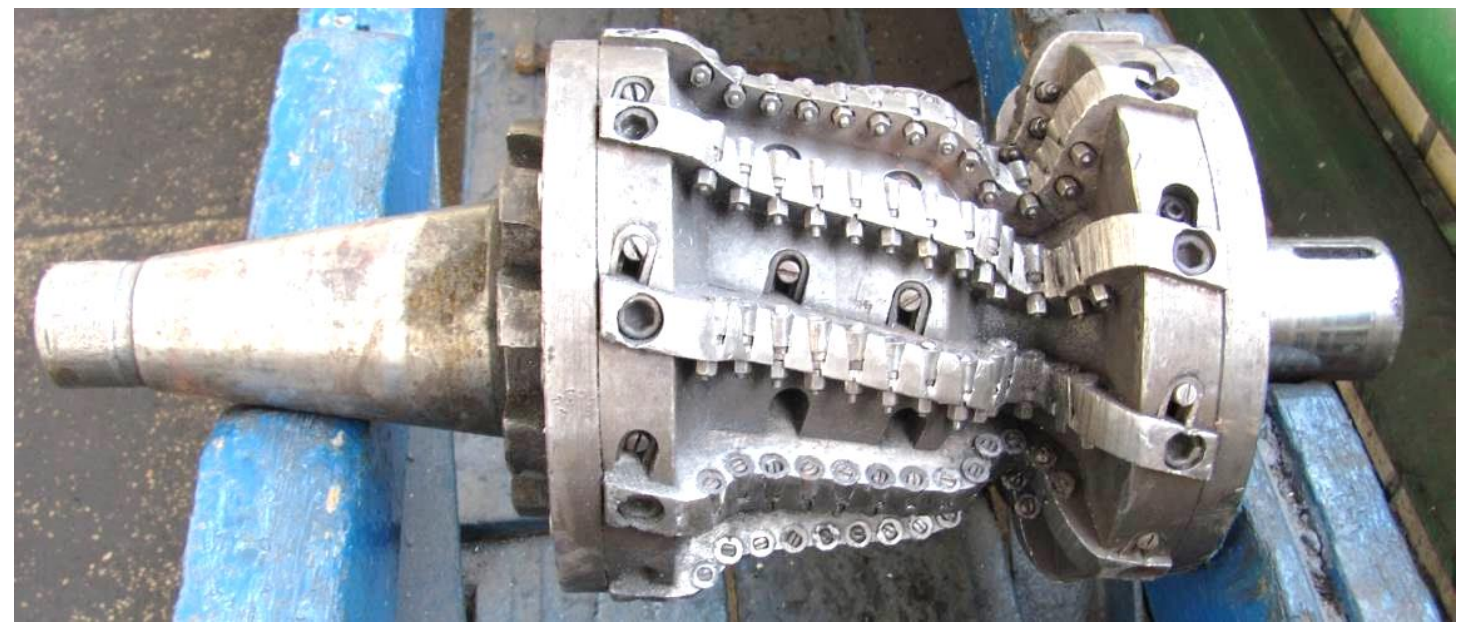

Figure 6. Form mill for KZh20 machine tool

Mills are intended for machining (profile restoration) of wheelsets [16-18] without rolling off the electric locomotives and diesel locomotives on wheel milling machines. The mills work in a set of two pieces - right and left, while machining both wheels of the wheelset.

The process of eliminating the defects has the following sequence. The combined form mill is established on KZh20 wheel milling machine which is in the trench under rails and gives free passage of the locomotive over the machine. The locomotive is mounted on the machine in the position of milling with a shunting winch, the wheel pair rests on the four drive rollers of the machine. Two central heads of the KZh20 wheel milling machine center the wheelset on the central sockets of the wheelset axis. Form mills are alternately brought to each wheel of the wheelset and are established for restoration of the rolling surface profile. Cutting of mills is made gradually on the site of 350-400 $\mathrm{mm}$ circle. The process of complete restoration is carried out in one revolution of the wheelset under the locomotive. The size of the feed and the depth of the cut are selected depending on the state of the profile of the wheelset. The recommended cutting modes are indicated in the passport of the wheel milling machine tool. After each wheelset machining it is necessary to test the condition of cutting elements. In order to increase the service life of the cup cutters, they should be rotated along the axis, and cylindrical cutters with chipping or extreme wear should be replaced before the next wheelset machining.

All the above listed designs of form mills are identical, knives in the case of the mill are fixed by face covers, wedges and screws and differ in the form of the received working profile.

The cutters are installed with one end having a cone in the spindle of the machine, and the other end having a cylindrical shank - in the support element of the machine.

Mills consist of 10 knives with the form profile, each having 12 cutters with center-to center spacing cutter diameter plus $1.8 \mathrm{~mm}$ are established on the average.

Since the working profile of the wheelset, as a rule, have sliders, it is recommended to process them at a constant cutting speed $60-80 \mathrm{~m} / \mathrm{min}$. even in cases where there are no slides.

Application of this cutting speed protects shaped mills from excessive wear and chips of hard-alloy cylindrical cutting elements. The cutting speed of $60-80 \mathrm{~m} / \mathrm{min}$ is achieved by installing replaceable gears, which provide $93-120 \mathrm{rpm}$. spindle per minute. The value of the minute feed is selected in the range of $100-150 \mathrm{~mm} / \mathrm{min}$ 
Less values of feeds by $25-30 \%$ are to be applied during machining of wheelsets of shunting locomotives and in those cases when depth of cutting exceeds $5 \mathrm{~mm}$. Before machining it is necessary to check compliance of tabular and actual circular giving.

Cutting of mills is necessary for carrying out short pulses. If the amount of wheelset is up to $4 \mathrm{~mm}$, the incision must be made at a length of $300 \mathrm{~mm}$, more than $4 \mathrm{~mm}$ at a length of $400 \mathrm{~mm}$. If the cut length is short, the drive rollers may slip.

These mills are used not only for mainline transport, but also in the locomotive facilities of industrial transport. In this case, the service life of such tool on industrial transport is usually significantly shorter. This is due to more difficult operating conditions of locomotive wheels, which, in turn, results in premature wear with the occurrence of sliders, welds and other defects that require special modes of milling wheelsets. For example, under the conditions of mining and metallurgical complex operation, the service life of interlocking cutters is 3-6 months. Then repair with replacement of hard-alloy cutters and painstaking work on adjustment of the mill on the corresponding working profile of the wheel surface is required.

The disadvantage of these cutter designs is that due to the relatively large lengths of the cutting edges and, consequently, the cutting perimeters, in the system «machine - device tool - part» (MDTP) there are vibrations that dramatically reduce the service life of the tool and machining productivity. Cutting elements (Figure 7, a), which are destroyed or have chips are usually replaced. Knives (Figure 7, b) fail due to abrasion of the outer surface.

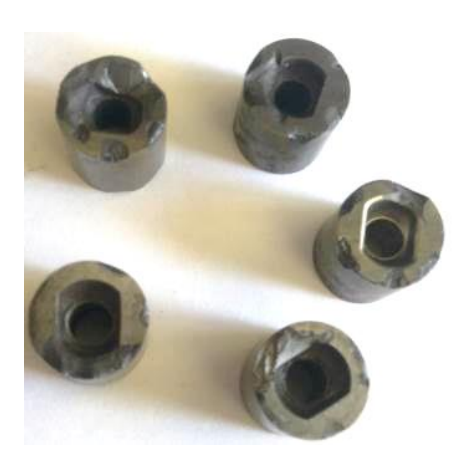

a)

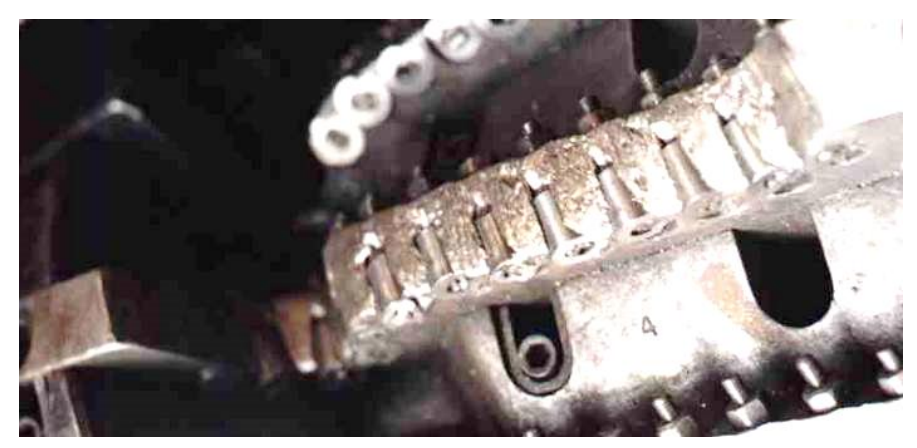

b)

Figure 7. Defects obtained during the operation of special form mills: a) cutting elements; b) worn surface of the tool holder

Wear of the surface of the tool holder, due to abrasion of the outer surface results in greater disclosure of the cutting elements.

The importance of the problem of extending the service life of milling cutters is beyond doubt. One of the main reasons is the quality of threaded parts.

Despite the widespread use and long-term practice of using threaded joints, the problem of the impact on their strength of manufacturing technology and the basic parameters of the thread remains unresolved. Making high-precision threads is rather complex and timeconsuming operation, which requires a large cost of thread-forming and measuring tools, and is accompanied by a large percentage of dimensional defects.

Threaded elements (Figure 8, a), with M4 thread diameter, fastening the cutting elements in the body of the cutter holder (knife) can be stretched and torn.

Bolts with a thread with M8 diameter are bent, the head of the bolt with internal hexagon collapses, and wedge-shaped crackers wear out (Figure 8, b). For example, in (Figure 8, c) overload of the thread of M12 bolts due to the lack of crackers and M8 bolts results in crumpling of M12 thread and even the rupture of the bolts securing the toolholders in the housing, (Figure $8, \mathrm{~d})$ shows the fragment of the body of the cutter, in which there are no wedge-shaped crackers. 


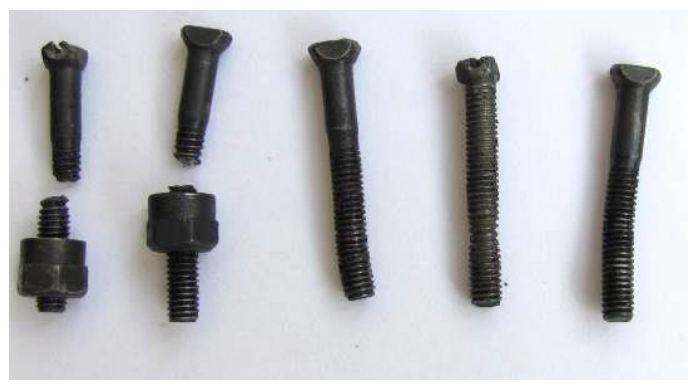

a)

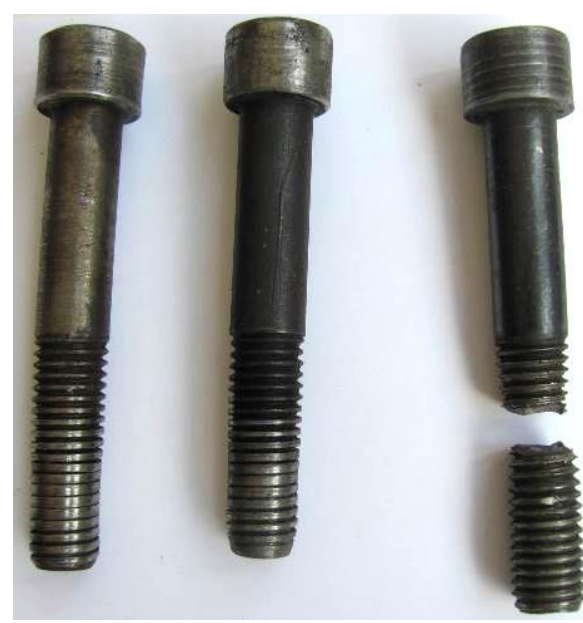

c)

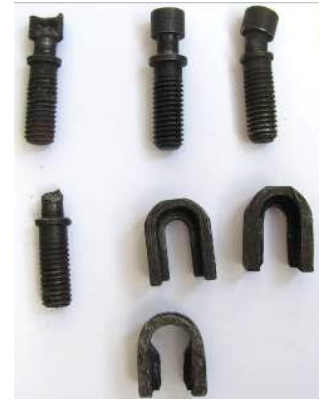

b)

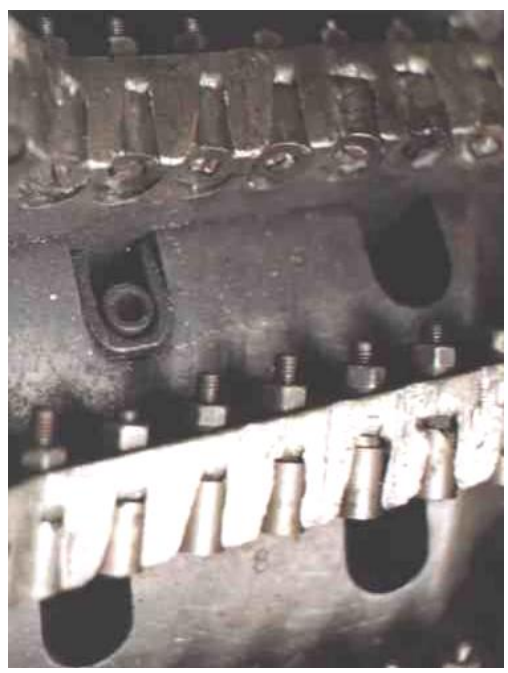

d)

Figure 8. Threaded elements

The mechanism of defects occurrence is a set of mechanical, thermophysical and chemical phenomena and is associated with the formation of wear particles and microcracks in places of intense plastic deformation that occur during operation.

Permissible stresses $[\sigma]_{p}$ under the action of the constant load on the threaded connection are chosen depending on the yield strength $\sigma_{T}$ of the screw material (bolt) [19]:

$$
[\sigma]_{p}=\frac{\sigma_{T}}{S}
$$

where $S$ is the stock ratio, which is $1.5 \ldots 2.5$. The stress state of a cutting tool can now be successfully modeled using the finite element method.

Under cyclic loads, in contrast to static ones, the strength of threaded connections depends not only on the weakest point - the cut part of the bolt, but also on the design of other elements of the threaded connection. The strength of threaded joints, other things being equal, depends on the concentration of stresses arising from their deformation, the nature of the distribution of forces between the turns of the thread on the length of screwing and contact stresses arising from the influence of turns of the thread on the turns of the bolt. 
The above listed defects (Figure 8) result in weakening of apertures for cutting elements, together with opening of cutting elements. It can lead to turning out (Figure 9, a) of cutting elements or a rupture of a jumper between cutting elements (Figure 9, b).

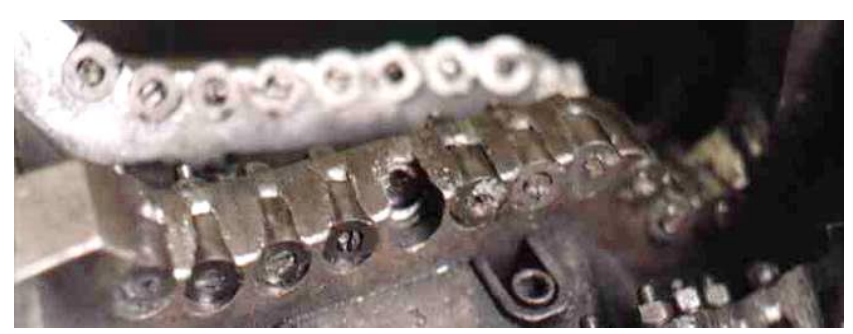

a)

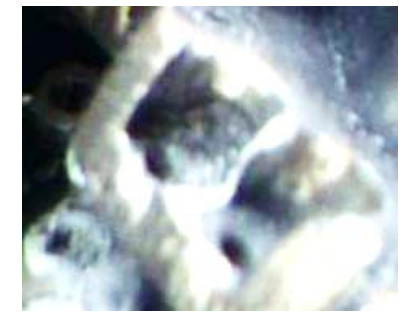

b)

Figure 9. Defects of the tool holder

Errors of the operator of KZh20 machine tool result in sealing (Figure 10) of the cutter. At such defects it is necessary to replace the cutter holder, and it is possible and all cutter holders of the form mill.

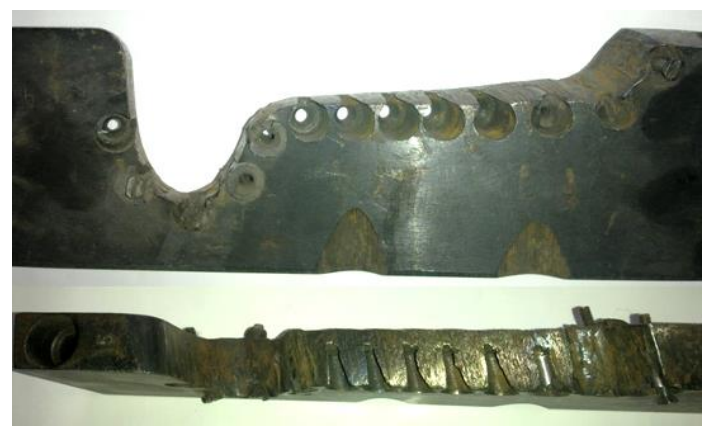

Figure 10. Tool holder with sealed cutters

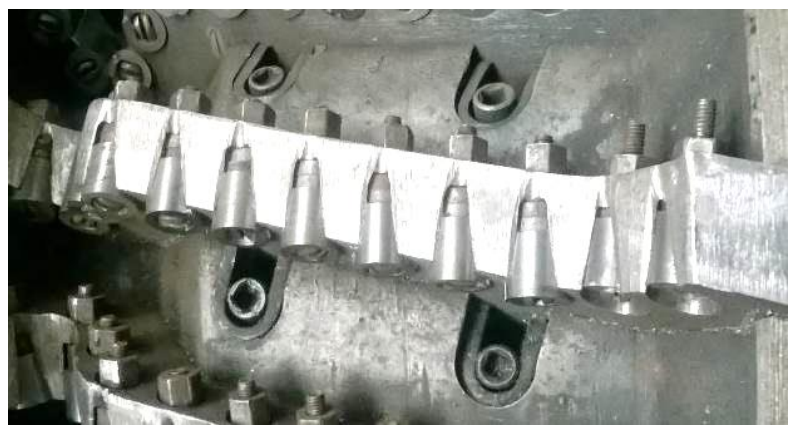

Figure 11. Tool holder with manufacturing defect

It is also necessary to determine the defects in the manufacture of tool holders (knives) (Figure 11). Due to the deep milling of the socket under the cylindrical cutting element, a larger thickness of the compensating washer is required to perform the profile, while the cutting element protrudes beyond the body of the tool holder up to $3-4 \mathrm{~mm}$. Such protruding cutting element can be turned. The connection is also loosened by installing two compensating washers instead of one.

The defects can be divided into two main groups. The first group consists of factors related to the manufacture and preparation (adjustment) of the tool for work. The second group consists of factors directly related to the milling process.

The most significant factors of the first group are: quality of formation of linear and angular parameters of nests for cutting elements in cutter holders (knives) of shaped mills, roughness of surfaces, accuracy of assembly, accuracy and rigidity of technological system, quality of tool material. Their impact can be reduced by improving the quality of production at all stages of tool preparation.

The second group of defects is determined by the modes in the process. Their analysis is the basis for selecting the optimal operating parameters that meet the requirements of accuracy and quality of milling, productivity and reliability of the tool. 
The factors that mostly affect the cutter include the resistance to cutting. The temperature factor and centrifugal forces are of secondary importance, as the cutters operate at low cutting speeds (up to $80 \mathrm{~m} / \mathrm{min}$ ).

Numerous works are devoted to the determination of cutting forces. Chip thickness during milling - the value is variable and depends on the angular position of the cutter holder on the contact arc. The influence of cutting speed, geometric parameters of tool holders, physical and mechanical properties of tool and machined materials, type and location of cutting edges and other factors have been studied in [20,21, 22].

According to the results of the analysis, the authors believe that the reduction of these defects formation can be achieved by the increase of cutting elements number [22], which simultaneously reduces the load on each cutting element.

For the design of processes of tooling of details the method of eventual elements is most often used. Articles [23, 24] sanctified to the numeral design of process of tooling of different details with the use of this method.

Conclusions. The most characteristic defects of special form mills are determined. According to their influence on the service life of the cutter, two groups of destructions are distinguished. The first group consists of damage and chipping or destruction of the cutting edge of the cutting elements, which can be eliminated by replacing the cylindrical cutting elements.

The second group consists of cracks in the cutter holder (knives) and its complete destruction. The destruction is taken out of operation by special shaped cutters, which characterize the features of the load when restoring the reinforced areas of the working surface of the wheelsets.

These defects are the result of a wide range of causes that are closely related. Among them, there are two main groups of factors: related to the manufacture and preparation of the tool for work and related to the process. The impact of defects of the first group can be significantly reduced by improving the production culture at all stages of tool manufacturing. The second group of defects is determined by the processing modes. Thus, the task for further investigation of the working capacity of special form mills for KZh20 machine tools is important.

\section{References}

1. Mazur N. P., Vnukov Yu. N., Grabchenko A. I. i dr. Osnovyi teorii rezaniya materialov: uchebnik [dlya vyissh. uchebn. zavedeniy]; podobsch. red. N. P. Mazura i A. I. Grabchenko, 2-eizd., pererab. i dopoln. Harkov: NTU "HPI",2013. 534 p.

2. Pat. № 25091 Ukrayini, MPK V 23 S 5/11. 5/14. Fasonna freza dlya vIdnovlennya profllyu kolesa ruhomogo skladu zallznichnogo transportu. Kolot V. O., Malinovskiy M. D., Lishaev G. P., SergIEnko M. I., Korotun S. A., Kolot O. V.; zayavnik ta pravovlasnik Zakrite aktsIonerne tovaristvo “MINETEK”, Derzhavna admInIstratsIya zalIznichnogo transportu UkraYini, opubl. 25.12.98, Byul. № 6. $7 \mathrm{p}$.

3. Pat. № 25406 UkraYini, MPK V23 S5/00. ZbIrna fasonna freza. Shapovalov V. F., Kolot V. O., Lishaev G. P., Anastasov S. L., zayavnik ta pravovlasnik Zakrite aktsIonerne tovaristvo "MINETEK", opubl. 25.12.98 r, Byul. № 6.5 p.

4. Sladkovskiy A. V. Teoreticheskoe obosnovanie i razrabotka ratsionalnyih konstruktsiy paryi koleso - rels dlya relsovyih gorno-transportnyih mashin i agregatov: dis. ... d-ra tehn. nauk: 05.15.16 / Aleksandr Valentinovich Sladkovskiy; Gosudarstvennaya metallurgicheskaya akademiya Ukrainyi. Dnepropetrovsk, 1997. $362 \mathrm{p}$.

5. Handozhko, A. V. \& Timoschenko, A. A. \& Petrusenko, L. A. Analiz faktorov, vyizyivayuschih hrupkoe razrushenie tverdosplavnogo rezhuschego instrumenta. Nadezhnost instrumenta i optimizatsiya tehnologicheskih sistem. Kramatorsk. 2016. No. 38. P. 175-184.

6. Plastinyi dlya obrabotki kolesnyih par i relsov. RNUX 1212 M0 TN. URL: http://www.kzts.com/ products.html\#product 4 .

7. Stanray TN-84C Underfloor Wheel Truing Machine. URL: http://smtgroup.com/railway-wheel-shopequipment/underfloor-technology/underfloor-wheel-truing-machine-stanray.

8. InstruktsIya $\mathrm{z}$ formuvannya, remontu ta utrimannya kolIsnih par tyagovogo ruhomogo skladu zallznits Ukrayini kolIyi 1520 mm. VND 32.0.07.001-2001: Zatverdzheno Nakazom UkrzalIznitsI vId 29.05.2001 № 305-Ts zI zmInami ta dopovnennyami zatverdzhenimi nakazami UkrzalIznitsI vId 16.11.2004 № 863- 
TsE, vid 18.12.2007 № 598-Ts ta vId 20.04.2010 № 046-TsZ. MIntrans Ukrayini. UkrzalIznitsya. Gol. lokomotiv. gosp. Kyiv. 2011.

9. Remont kolesnyih par. URL: http://dieselloc.ru/remont-eps/remont-kolesnykh-par.htm.

10. VIkIpedIya. UkrzalIznitsya. URL: https://uk.wikipedia.org/wiki/UkrzalIznitsya.

11. UkrzalIznitsya. URL: http://www.uz.gov.ua/press_center/up_to_date_topic/448552/.

12. Zheleznodorozhnyiy transport. URL: http://www.kzts.com/products.html\#product4.

13. Zaporozhskaya direktsiya zheleznodorozhnyih perevozok [Elektronnyiy resurs]. URL: https:// ru.wikipedia.org/wiki/Zaporozhskaya_direktsiya_zheleznodorozhnyih_perevozok.

14. Gazeta metallurg. URL: http://ukraine.arcelormittal.com/index.php?id=126\&p=402.

15. ChAO KZTS. URL: https://hi-in.facebook.com/PAOKZTS/posts/2610964478952796.

16. Kolesnyie paryi dlya teplovozov i elektrovozov zheleznyih dorog kolei $1520 \mathrm{~mm}$. Tehnicheskie usloviya: GOST 11018-2011. Vved. 01.01.2013. M., 2012. 32 p.

17. Bandazhi chernovyie dlya zheleznodorozhnogo podvizhnogo sostava. Tehnicheskie usloviya: GOST 3982010. Data vvedeniya 2011-09-01. M., 2011. 22 p.

18. Zheleznodorozhnyie kolesa i bandazhi KLW. URL: http://www.interpipe.biz/upload/catalog/ 2014021111202077629c7bd0368350bc29e8adc056cd86.pdf.

19. Rud Yu. S. Osnovi konstruyuvannya mashin: PIdruchnik dlya studentIv Inzhenerno-tehnIchnih spetsIalnostey vischih navchalnih zakladIv.2-e vid., pererobl. Kriviy RIg: Vidavets FO-P Chernyavskiy D. O., 2015. 492 p.; z il.

20. Sladkovskiy A. V., Hmilenko V. S., Ruban V. N. Vosstanovlenie profilya rabochey poverhnosti kolesnyih par mashin relsovogo transporta metallurgicheskih predpriyatiy i GOKov. Sbornik nauchnyih trudov Natsionalnoy gornoy akademii Ukrainyi. 2002. No. 13, t. 2. P. 132-136.

21. Ruban V. N. Opredelenie energosilovyih parametrov pri vosstanovitelnom remonte profilya poverhnosti kataniya kolesnyih par mashin relsovogo transporta na stanke KZ20. Teoriya i praktika metallurgii. No. 12 (96-97). 2014. P. 46-51.

22. Sładkowski A., Proydak Yu., Ruban V. Increasing the resource of milling cutters used to process the locomotive wheelsets. Part 1: Determination of cutting forces. Transport Problems. 2018. Vol. 13. No. 3. P. 119-130. ISSN 1896-0596. https://doi.org/10.20858/tp.2018.13.3.11

23. Pryhorovska T., Pryhorovskyi O. Finite-element simulation of PDC drill bit's operational stress-strain state. Scientific Journal of TNTU (Tern.) 2020. Vol. 97. No. 1. P. 45-56. https://doi.org/10.33108/ visnyk_tntu2020.01.045

24. Hlembotska L., Balytska N., Melnychuk P., Melnyk O. Computer modelling power load of face mills with cylindrical rake face of inserts in machining difficult-to-cut materials. Scientific Journal of TNTU (Tern.) 2019. Vol. 93. No. 1. P. 70-80. https://doi.org/10.33108/visnyk_tntu2019.01.070

\section{Список використаної літератури}

1. Мазур Н. П., Внуков Ю. Н., Грабченко А. И. и др. Основы теории резания материалов: учебник [для высш. учебн. заведений] / под общ. ред. Н. П. Мазура и А. И. Грабченко. 2-еизд., перераб. и дополн. Харьков: НТУ «ХПИ»,2013. 534 с.

2. Колот В. О., Малиновський М. Д., Лишаев Г. П., Сергієнко М. І., К Коротун С. А., Колот О. В. Фасонна фреза для відновлення профілю колеса рухомого складу залізничного транспорту: пат. № 25091 України, МПК В 23 С 5/11. 5/14. Заявник та правовласник Закрите акціонерне товариство «МІНЕТЕК», Державна адміністрація залізничного транспорту України; опубл. 25.12.98, Бюл. № 6. 7c.

3. Шаповалов В. Ф., Колот В. О., Лишаев Г. П., Анастасов С. Л. Збірна фасонна фреза: пат. № 25406 України, МПК В23 С5/00. Заявник та правовласник Закрите акціонерне товариство «МIHЕТЕК», опубл. 25.12.98 p, Бюл. № 6.5 с.

4. Сладковский А. В. Теоретическое обоснование и разработка рациональных конструкций пары колесо - рельс для рельсовых горно-транспортных машин и агрегатов: дис. ... д-ра техн. наук: 05.15.16 / Государственная металлургическая академия Украины. Днепропетровск, 1997. 362 с.

5. Хандожко А. В. \& Тимощенко А. А. \& Петрусенко Л. А. Анализ факторов, вызывающих хрупкое разрушение твердосплавного режущего инструмента. Надежность инструмента и оптимизация технологических систем. Краматорск. 2016. № 38. Р. 175-184.

6. Пластины для обработки колесных пар и рельсов. RNUX 1212 M0 TN. URL: http://www.kzts.com/ products.html\#product4.

7. Подрельсовый станок для обточки колесных пар Stanray TN-84C. URL: http://smtgroup.com/railwaywheel-shop-equipment/underfloor-technology/underfloor-wheel-truing-machine-stanray.

8. Інструкція з формування, ремонту та утримання колісних пар тягового рухомого складу залізниць України колії 1520 мм. ВНД 32.0.07.001-2001: Затверджено Наказом Укрзалізниці від 29.05.2001 № 305-Ц зі змінами та доповненнями затвердженими наказами Укрзалізниці від 16.11.2004 863-ЦЭ, від 18.12.2007 № 598-Ц та від 20.04.2010 № 046-ЦЗ. Мінтранс України. Укрзалізниця. Гол. локомотив. госп. Київ. 2011.

9. Ремонт колесных пар. URL: http://dieselloc.ru/remont-eps/remont-kolesnykh-par.html.

10. Вікіпедія. Укрзалізниця. URL: https://uk.wikipedia.org/wiki/\%D0\%A3\%D0\%BA\%D1\%80\%D0\%B7\% 
D0\%B0\%D0\%BB\%D1\%96\%D0\%B7\%D0\%BD\%D0\%B8\%D1\%86\%D1\%8F.

11. Укрзалізниця. URL: http://www.uz.gov.ua/press_center/up_to_date_topic/448552/.

12. Железнодорожный транспорт. URL: http://www.kzts.com/products.html\#product4.

13.Запорожская дирекция железнодорожных перевозок. URL: https://ru.wikipedia.org/wiki/ Запорожская_дирекция_железнодорожных_перевозок.

14. Газета металлург. URL: http://ukraine.arcelormittal.com/index.php?id=126\&p=402.

15. ЧАО КЗТС. URL: https://hi-in.facebook.com/PAOKZTS/posts/2610964478952796.

16. Колесные пары для тепловозов и электровозов железных дорог колеи 1520 мм. Технические условия: ГОСТ 11018-2011. Введ. 01.01.2013. М., 2012. 32 с.

17. Бандажи черновые для железнодорожного подвижного состава. Технические условия: ГОСТ 3982010. Дата введения 2011-09-01. М., 2011. 22 с.

18. Железнодорожные колеса и бандажи KLW. URL: http://www.interpipe.biz/upload/catalog/ 2014021111202077629c7bd0368350bc29e8adc056cd86.pdf.

19. Рудь Ю. С. Основи конструювання машин: Підручник для студентів інженерно-технічних спеціальностей вищих навчальних закладів. 2-е вид., переробл. Кривий Ріг: Видавець ФО-П Чернявський Д. О., 2015. 492 с.

20. Сладковский А. В., Хмиленко В. С., Рубан В. Н. Восстановление профиля рабочей поверхности колесных пар машин рельсового транспорта металлургических предприятий и ГОКов. Сборник научных трудов Национальной горной академии Украины. 2002. № 13. Т. 2. С. 132-136.

21. Рубан В. Н. Определение энергосиловых параметров при восстановительном ремонте профиля поверхности катания колесных пар машин рельсового транспорта на станке КЖ20. Теория и практика металлургии. № 1-2 (96-97). 2014. С. 46-51.

22. Sładkowski A., Proydak Yu., Ruban V. Increasing the resource of milling cutters used to process the locomotive wheelsets. Part 1: Determination of cutting forces. Transport Problems. 2018. Vol. 13. No. 3. P. 119-130. ISSN 1896-0596. https://doi.org/10.20858/tp.2018.13.3.11

23. Pryhorovska T., Pryhorovskyi O. Finite-element simulation of PDC drill bit's operational stress-strain state. Вісник ТНТУ. 2020. Vol. 97. No. 1. Р. 45-56. https://doi.org/10.33108/visnyk_tntu2020.01.045

24. Глембоцька Л., Балицька Н., Мельничук П., Мельник О. Комп’ютерне моделювання силового навантаження ножів торцевих фрез 3 циліндричною передньою поверхнею при різанні важкооброблюваних матеріалів. Вісник ТНТУ. 2019. Vol. 93. No. 1. P. 70 80. https://doi.org/10.33108/ visnyk_tntu2019.01.070

\title{
УДК 621.914.1
}

\section{ДЕФЕКТИ СПЕЦАЛЬНИХ ФАСОННИХ ФРЕЗ ДО ВЕРСТАТА КЖ20}

\section{Олександр Сладковські ${ }^{1}$ Владислав Рубан²}

\author{
${ }^{1}$ Сілезький технічний університет, Катовіцее, Польщза \\ ${ }^{2}$ Національна металургійна академія Украӥни, Дніпро, Украӥна
}

\begin{abstract}
Резюме. Важливим завданням машинобудування $\epsilon$ підвищення продуктивності оброблення, покращення експлуатаційних властивостей різального інструменту та оптимізація режимів різання. В локомотивних депо для відновлення робочого профілю колісних пар без викочування з-під локомотива використовуються спещіальні фасонні фрези для колесофрезерних верстатів КЖ20. Спещіальна фасонна фреза є різальним інструментом, у якого різальна кромка не паралельна осі обертання $і$ є сукупністю кривих і прямих ліній, а профіль робочої поверхні колеса утворюється в результаті обертання різальної кромки відносно осі інструментуаСтійкість інструмента зумовлено умовами експлуатації локомотивних коліс, ще, призводить до передчасного зносу з появою повзунів, наварів та інших дефектів, які вимагають особливих режимів фрезерної обробки колісних пар. Визначено найхарактерніші дефекти спеціальних фасонних фрез до верстата КЖ20. За впливом на ресурс роботи спеціальних фасонних фрез виділено дві основні групи дефектів, щуо пов'язані з якістю виготовлення й підготовкою інструмента до роботи, а також з режимами оброблення.
\end{abstract}

Ключові слова: спеціальні фасонні фрези, колесофрезерний верстат КЖ20, різальні елементи, відмови спеціальних фасонних фрез, надійність, стійкість. 